\title{
DIASPORA AND HYBRIDITY IN AHDAF SOUIF'S AISHA
}

\author{
Walid Abdallah Rezk \\ A lecturer in English language and literature \\ Faculty of Arts - Suez University
}




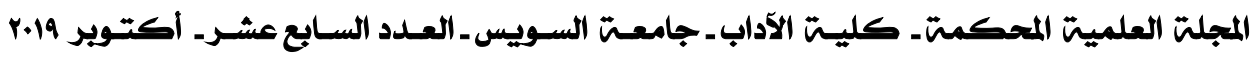


Ahdaf Soueif's novels and short stories mainly tackle the misinterpretations that move in the spaces between East and West. Aisha (1983) reads as an authentic, original literary production that has been written by this original and creative Arab female writer, whether we regard it as belonging to Arab literature, or to English literature or even Euro-Arab literature. It does not only explore these misconceptions but also puts forward so many questions about clash of cultures, hybridity, politics, the history of Egypt and life there. Since the second half of past century, questions related to identity have been regularly asked, resulting from the increased impact of globalization and cultural hybridization. Culture is one of the bases that play a great role in shaping and determining one's identity. In soueif's Aisha, cultural difference has led to inner and outer identity crises of a lot of characters, it is certainly not a process that occurred over night, but transformations need time, as in Aisha's case when she travelled all the way from Egypt to England. Connected with identity crisis, are two postcolonial key terms namely hybridity and Diaspora which not only gave rise to identity crisis but triggered it time and again through character's course of actions. It is not only Aisha, the protagonist of novel, who is affected after crossing borders, but her husband too has gained a greater degree of English culture's influence. These characters could not escape the 
danger of being mixed into alien culture and religion by living in a Western country. Aisha tried to secure herself from becoming a victim of identity crisis resulting from Hybridity and Diaspora. Identity crisis, Diaspora and Hybridity are interconnected terms when it comes to culture and especially when it underlines the religion. These elements are the core of postcolonialism which refers to the period after the dissolution of colonial powers in the world.

Keywords: hybridity, diaspora, clash of cultures, postcolonial writings, displacement, alienation, and cross-cultural.

Ahdaf Soueif (March 23, 1950) is an Egyptian writer, who was born in Cairo. She spent nearly four years of her childhood in England while her mother was doing her $\mathrm{PhD}$ at London University. Then, in 1973, she went back to England to study for her doctorate in linguistics at Lancaster University as she is a professor at Cairo University. Because Soueif lived in two different cultural backgrounds, Arabic and British, her work shows great influence from both literary backgrounds. She is married to the English poet and biographer Ian Hamilton. She is the author of three collections, Aisha (1983), Sandpiper (1996) and I Think of You (2007). Further, Soueif wrote two novels, In the Eye of the Sun (1992) and The Map of 
Love (1999), which established her as one of the best Arab female novelists writing in English. In fact, most of her short stories and novels are based on her personal experiences in life; most of her female characters encounter love and loss, western repulsion, diaspora, hybridity and cultural clashes. Moreover, Soueif is a political and cultural commentator in English and Arabic. She wrote several essays and reviews, which were published in some famous journals and magazines such as the Guardian, the London Magazine and El Shrouk.

In the beginning, it is worthwhile to explore the postcolonial domain and Oriental thought in which Ahdaf Soueif is mainly integrated and which she embosses with her works of fiction in addition to critical writing. The domain of postcolonialism is quite vast and complicated and this paper aims to show the complexity of the trend of postcolonial literature based on postcolonial theory and criticism. There are a lot of issues which are common to the wide and disparate postcolonial literature and all of them are related to the colonial past and present. A lot of these issues are presented Ahdaf Soueif's books.

This paper is intended to analyze Ahdaf Soueif's collection of short stories entitled Aisha, which contains some female characters from different cultural backgrounds and to 
analyze their major roles according to the concepts of postcolonial theory. It explores the integration of post-colonialism theory in examining women's diaspora, hybridity and clash of cultures as well as shedding light on the sufferings of women being torn between what is traditional and what is modern and between East and West. How these female heroines face clashes of culture whether they come from the outer world or those which come from inside.

Both the terms of Hybridity and diaspora are the outcome of people's leaving their original countries and moving to new countries carrying with them their customs, traditions and culture and mix them with the new culture of the new world and as a result we get a new mixture of traditional and new values. There are different definitions of these two terms, but the most common are, on the one hand 'Hybridity has been shown to be a constituting characteristic of social interaction resulting mainly from the contemporary globalization of communication and from the effects of communication in spaces of fuzzy or merging borders, which in turn affect cultural and linguistic identities' (Schaffner \& Adab, 2001, p.301).

Connected with or even the cause of identity crisis is the term 'Diaspora'. As Ashcroft et.al (1989) follows the root of 
Diaspora by finding its origin in Greek word 'Diaspeir' meaning 'to disperse', he goes on saying that "it is the voluntary or forcible movement of peoples from their homelands into new regions". Moreover, George (1996) focuses on the historical background of Diaspora by stating that the term of Diaspora is not restricted to the Jewish migration from their homeland, but it covers the millions of people living outside their own countries. About Diaspora Clifford (1994) says that it is a combination of emotions connected with homeland and the place of settlement. The second term which defines identity crisis is 'hybridity' which is mainly the meeting point of two contrasting cultures and a factor responsible for arousing identity crisis. Ashcroft et.al (1989) define hybridity as "the creation of new transcultural forms within the contact zone produced by colonization that is linguistic, cultural and political". But some scholars also favour the positive aspect of Hybridity which gives rise to new form of culture. Furthermore, Imtiaz and Asif (2011) state that Hybridity is not violation of the rights of colonizes as a result of globalization rather an advent of a new form of culture. Shaped by the colonizer, which leads to the empowerment of the colonized. Hybridity also creates a new form of identity resulting from differences in culture. Bhaba (1994) regards 
Hybridity as 'in-between' or 'interstitial' space that is an outcome of differences among cultures.

In order to achieve this objective, the post-colonial approach will be adopted to highlight diaspora, hybridity and clash of cultures of women within the selected short stories of the study. Ahdaf Soueif is the outcome of a double Eastern and Western childhood and education, a life distinguished with a combination of various cultures, which is mainly connected to postcolonial literature with hybrid identity. Ashcroft, Griffiths, and Tiffin in Post-colonial Studies, The Key Concepts (1998) define the term hybridity as, "one of the most widely employed and most disputed terms in post-colonial theory, [which] commonly refers to the creation of new transcultural forms within the contact zone produced by colonization."(118). Authors who lived in that postcolonial period move between various worlds, trying to combine different cultures. This mixture of diverse cultures has led these postcolonial authors to a fusion of different audiences, which, in turn, has given them a variety of levels of worrying and estimation.

Ahdaf Soueif is not definitely the only Arab female writer who use English for their works of fiction. Although most Arab writers use their mother tongue to express their ideas and produce their works of fiction, there are a lot of 
writers from the Arab world coming from different cultural backgrounds who use a foreign language like English, Italian, French, Spanish or German. It is a distinguished literary phenomenon, and Ferial J. Ghazoul states in The Hybrid Literary Text (2000):

What (they have) in common beyond their special and distinctive regional characteristics is that they have emerged in their present form out of the experience of colonization and asserted themselves by foregrounding the tension with the imperial power, and by emphasizing their differences from the assumptions of the imperial centre. It is this which makes them distinctively post colonial. (6)

According to what Ghazoul mentions, the literature that they produce is called post-colonial literature. Although many critics have different points of view in defining the postcolonial literature, Chris Baldick defines it in The Oxford Dictionary of Literary Terms (2008) as follows:

It thus covers a very wide range of writings from countries that were once colonies or dependencies of the European powers... In practice, the term is applied most often to writings from Africa, the Indian sub-continent, the Caribbean, and other regions whose histories during the 20th century are marked by colonialism, anti-colonial movements, 
and subsequent transitions to post-Independence society. Critical attention to this large body of work in academic contexts is often influenced by a distinct school of postcolonial theory which developed in the 1980s and 1990s, under the influence of Edward W. Said's landmark study Orientalism (1978). (312)

The above-mentioned definition confirms that Ahdaf Soueif is a post-colonial writer as she was born and raised in Egypt which lies in Africa and used to be occupied by Great Britain for more than seventy years, and this, without doubt, left a deep impact on the culture of the Egyptian society to which Ahdaf Soueif belongs.

The method applied in this study is based on tracing common features and causal continuities that might be there between the post-colonial style and the short stories of Ahdaf Soueif. It is crystal-clear that Soueif's work is a direct reflection of the main principles of post-colonialism, whose main concepts are diaspora, displacement, hybridity and clash of culture. It is immensely challenging to prove that her works added much to the post-colonial movement in the Middle East because while writing Aisha, she was writing a great part of her personal experiences of a female Muslim who lived both in the east and the west and suffered deeply from clash of culture. I 
think Soueif, along with others like Nawal as-Saadawi, Hanan al-Shaykh, Fadia Faqir, Ahlam Mosteghanemi, and Salwa Bakr are the pioneers of post-colonialism literature in Arabic. They are able to achieve great success in presenting women issues and are able to change the stereotype image of the Arab Muslim women in their country and abroad.

Post-colonial writers tackle women's issues, as Gillan notes in In a Different Voice: Women's Conceptions of Self and Morality (1977), "such as in contract law, property, and voting while also promoting bodily integrity, autonomy, and reproductive rights for women." (30). All these issues are extensively discussed in Aisha. Ahdaf Soueif is concerned with representing the complication of cultural confrontations which can be seen as a motivation to identity development in addition to cultural hybridity. Her short stories shed light on how identity is developed through mutual cultural interpretation in a world that is mainly transcultural. The protagonists representing cultural confrontations do not only absorb or embrace the controlling culture of ex-colonizing community, but they are able to form their own original culture and mix it with the mainstream one to make their dreams come true. Such "merging" of cultures is, according to Welsch, a major quality of the current culture. He notes: 
the deep differences between cultures are today diminishing more and more, that contemporary cultures are characterized by cross-culturing elements -and in this sense are to be comprehended as transcultural rather than monocultural. (3)

The post-colonial movement affected writers and authors worldwide and as a result of that tremendous effect, there appeared fiction and non-fiction writings which created new interest in women's writing. Ahadaf Soueif, no doubt, contributes greatly to discussing women's issues particularly the clash of cultures and gives great example of women's innovation and creativity, and confirms what Blain notes in his book entitled The Feminist Companion to Literature in English from the Middle Ages to the Present (1990) about this movement, "It prompted a general reevaluation of women's historical and academic contributions in response to the belief that women's lives and contributions have been underrepresented as areas of scholarly interest"(91) Much of the early era of post-colonial theory was given over to the reawakening and recovery of texts written by women. Studies like “Dale Spender's Mothers of the Novel (1986) and Jane Spencer's The Rise of the Woman Novelist (1986) were groundbreaking in their insistence that women have always been writing." (91). Intertextuality, which is one of the main 
concepts of post-colonialism, has been revived because of the growth of interest in women's issues, a lot of publishers began to re-issue the novels of the nineteenth and early twentieth centuries. Gilbert in Paperbacks: From our Mothers' Libraries: Women Who Created the Novel (1986) mentions that Virago Press did the same thing and became one of "the first commercial presses to join in the project of reclamation. In the 1980s Pandora Press, responsible for publishing Spender's study, issued a companion line of 18th-century novels written by women" (1). Nowadays many other publishers care about republishing the early writings about women issues such as Broadview and the University of Kentucky. "A Vindication of the Rights of Woman (1792) by Mary Wollstonecraft, is one of the earliest works of feminist philosophy. A Room of One's Own (1929) by Virginia Woolf, is noted in its argument for both a literal and figural space for women writers within a literary tradition dominated by patriarchy." (2)

Soueif's Aisha tries to settle down such disputes between the East and the West by creating a paradise on earth where the members of these cultures might get on well with one another and live happily; it supports the exchange of cultures, habits and customs between the Western and the non-Western, ignoring power relations. Like Welsch's concept of existing commonalities among different people, Soueif's 


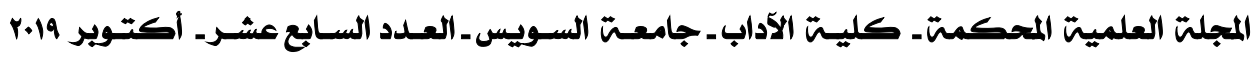

Aisha confirms the mutual harmony between East and West cultures that enhance fundamental human principles like love, justice, equality and care for arts. Soueif argues that in her "Mezzaterra":

We were modern and experimental. We believed in Art and science. We cared passionately for Freedom and Social Justice. We saw ourselves as occupying a ground common to both Arab and Western culture, Russian culture was in there too, and Indian, and a lot of South America. (5,6)

The Arab female writers have always been a fertile soil of research and analysis from western writers and critics alike; they always try to reveal the mystery of people living in that part of the world particularly women to answer questions that remain secret for several years and to settle down the clash of culture that remained for years and years.

For instance, Dalal Sarnou (2014) finds a growth of interest in the writings of Arab female writers whom she always calls Anglophone and hybrid. Interestingly, Sarnou shows that these writings, "mainly novels and short stories, have drawn great recognition and visibility to the Arab woman whose identity is perceived by the European readership as 
being different and complex, because of her portrayal in the media, as well as the books of early orientalists" (4).

Ahdaf Soueif is one among many other Arab writers who immigrated to Europe in the second half of the 20th century. She started from her new home to write about her own experiences with the other and based her stories on the struggle between her first identity and that of the new country and which deal with the inner conflict between the old and the new cultural customs and traditions. She creates clear position for herself in a collection of critical essays which she published in 2004 entitled Mezzaterra. Sindelarova who has lived in England for many years and who is classified as a postcolonial, feminist and Muslim Arab female writer argues that:

"The purpose of her writings is to focus on the portrayal of Arab-Muslim society and its striving for modernization in a globalized world. She formulates this objective in the context of a specific understanding of culture, cultural identity and intercultural relationship" (9).

There are numerous fundamental questions that will be examined in this paper: how is Soueif's Egyptian, and ArabMuslim origin respectively, reflected in her writings? Was she able to shed light on women's clash of culture between East 
and West and between inside and outside? To what extent did she succeed in showing the diaspora and hybridity that the Arab and Muslim women encounter in certain areas in the world? Was she able to change the viewpoint of the western reader of the Arab Muslim woman as an inferior creature torn between what is traditional and what is modern?

Aisha is a collection of short stories written to shed light on the different lives of women from various backgrounds. It was published in 1983 and got good criticism. The stories show the Egyptian women from different classes and religious backgrounds including Muslim and Christian heroines. In Egypt there are huge differences between the upper and lower classes. There is a huge gap between classes even in the way of thinking. The upper-class lives in comfort and luxury, while the lower classes are struggling and fighting for survival. Even though the women in Aisha have lived very different lives, they have a lot in common. They all do their best to be independent and resist the clash inside themselves and the clash against the outside world. This paper will focus on three main characters of the short stories, Aisha, Zeina and Mariana. As for Aisha, she represents the clash of West and East cultures and for Zeina and Mariana, they represent the clash between the traditions of the society and their inner rejecting of them. Somehow, all her protagonists are all related to the main 
character, Aisha. She comes from the upper-class and grew up in Cairo and London. Her parents are great Egyptian figures in the field of science. Aisha is the most affected character by western culture in the book, yet she suffers a lot in her relationship with her husband. After her quarrels and arguments with her husband she locks herself up in the bathroom and keeps crying until she loses consciousness. All the bathrooms she got into in London or Cairo witness how she suffered in her life. She has no one to complain to except her bathroom. During her life in London as a teenager, she lived in isolation from her white colleagues who were very happy with their boyfriends, she also looked at black girls who lived in minorities and she seemed too different from them and they looked at her in suspicion. Trabelsi describes the disillusion of a married woman who suffers from a deep clash of culture in the new society, and notes in his book Transcultural Writings: Ahdaf Soueif's Aisha as a Case Study (2003) that:

Apart from being a girl's name, with all the resonance from Arab-Islamic history, 'Aisha' contains the root 'aisha, life. The whole collection of short stories is in fact a call for life, a new life, after various lives married in distinctively gendered ways: the disillusion of married life...Aisha is about an Arab woman, struggling not only to survive, but mainly to carve out a place of her own -- a concern 


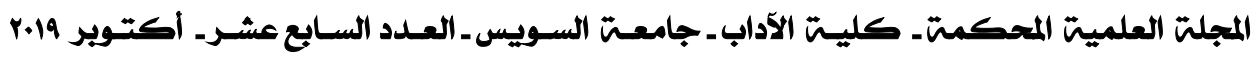

that shapes Soueif's later fiction as well. The whole matter hinges on East/West relations, years after decolonization. The idea is less to write back to the "empire" than to indulge in self-representation, thus inevitably resorting to values that may seem at first to be Western but which in fact transcend geographical boundaries (1)

Through Aisha's eyes, Ahdaf Soueif directs the reader towards the topics of diaspora, alienation and hybridity. In fact, Aisha has been shown as an alien with no origin, root or a country, as she was a Muslim in her early maturity; she was not accepted in the English Christian culture.

Vicar's children were the first people Aisha made friends with. They lived near where she lived. Now and then, they invited her to go with them to the church. At first, Aisha was so happy, thinking that she finally became one of them and accepted her as a Muslim girl, and began to pray together. She heard them saying this in their prayer "in our city today we find increasing numbers of people who come to us from far places; from alien races, alien beliefs. There are some of those among us tonight" (Soueif 32). Accordingly, Aisha realized that the Vicars meant her, considering Aisha, her family and people like her as aliens. Consequently, she felt lonely even if she was with them, at that time she realized that she doesn't belong to 
this British culture. Moreover, they asked her to become Christian, showing no respect to her religious belief as a Muslim "Should any person in this congregation wish to join with us in the love of Jesus Christ" (32). Therefore, for a second Aisha was speechless and could not breathe, realizing that she was the one they were talking about; being the only Muslim girl among the Vicar's children "I could not swallow. There was no doubt in my mind that he meant me" (32).

Because Aisha felt alienated from both the community and people surrounding her, she made up her mind to stay away from people, and decided she would never go with Vicar's children again "Mercifully, it did not happen... I had been-however unknowingly-betrayed, and I knew I would never go out with the Vicar's children again" (32), and she had a decision to have a world of her own, where she created fictional characters and enjoyed their company "I loved Maggie Tulliver, Anna Karenina, Emma Bovary and understood them as I understood none of the people around me" (29), Aisha felt that she was the queen and heroine of her imaginary world away from people, she felt that she belonged to that world more than the real one, which kept alienating and marginalizing her. Thus, through her experience with the Vicar's children, Aisha realized that the world she always dreamt of was not created yet. Whenever she returned to the 
present, she felt hopeless and lonely, as people around her stereotyped her religious belief.

Consequently, Aisha had a constant feeling of being marginalized, she usually heard racist and aggressive words from her new British friends "we find...people who come to us from far places; from alien races, alien beliefs" (32); the Vicars, whom they based their behavior and conduct towards her on their own stereotyped beliefs and assumptions, rather than the true image of a Muslim girl in particular, and Muslim women in general.

Aisha's parents were highly educated scientists. therefore, she was sent to a very good school where she could get good education and make new friends in the new society and this was the second deepest experience in her soul after Vicar's children. When Aisha got into her new comprehensive school, she made up her mind to hide her religious beliefs or anything that might show that she was a Muslim because she was frightened that she wouldn't be accepted among them, "I wasn't about to declare myself a Mohammedan, or even a Muslim" (Soueif 34).After that Aisha met a new classmate called Susan, who asked Aisha about her nationality and country. Indeed, when Aisha replied: "From Egypt" (35), Susan used to have a previous assumption that Egyptians are 
not civilized; "That's where they have those pharaohs and crocodiles and things... Do you go to school on a camel? Do you live in a tent" (35)?

Although Aisha came from a very cultured family and she was a good speaker of English, she found it hard to explain and clarify to Susan the truth behind her origin "I knew they were speaking Cockney and I was speaking proper English. But surely I was the one who was right" (35). Moreover, Susan had a firm assumption about Aisha's society that most Muslims believe in polygamy and suffered from poverty "How many wives does your father have? He doesn't have ten, then? Do you have bags of money?" (35).

Furthermore, Susan did not show any kind of respect to Aisha's Islamic principles and kept asking her embarrassing questions like "Do you have a boyfriend? Do you kiss him?" (Soueif 36). Consequently, Aisha again felt rejected, oppressed and marginalized, so her experience in the comprehensive school left a very deep scar on the wall of her heart. Aisha kept telling herself that "The white girls lived in a world of glamour and boyfriends to which I had no entrée" (37). Moreover, the black girls who were supposed to be suffering from the same feeling of inferiority, were looking at Aisha as being unfriendly "The black girls... regarded me with suspicious dislike" (37). 
Despite feeling rejected and marginalized, she did not surrender. Aisha was a good speaker of English, so she was able to answer her teachers' most questions very well, and this made her classmates feel jealous of her:

\section{"Mrs. Brathwaite...booming out, The Egyptian gets it every time. It takes someone from Africa, a foreigner, to teach you about your native language. You should be ashamed. At first, I was proud...But as the hostility grew, I realized I had made another mistake "(Souief 37).}

Over the time, Aisha felt lonely more and more in that aggressive and oppressive environment in her school, and she began to seek refuge in the library where she might find herself. "There, hidden in a corner, holding on to a hot radiator uninterrupted by cold blasts of air or reality" (38), or in the corner of the café where she used to listen to music through the Juke box "Music was magic to me. My secret bursts of life at the corner café sustained me, but at school things got steadily worse. The atmosphere in English became intolerable" (39). Moreover, she felt more marginalized on St Valentine's night "we joined some girls from my class for a while, but conversation was awkward, and we ended up standing alone by the wall" (41). Again, Aisha felt lonely and speechless" Time pass as I hung on waiting for something to happen while the 
evening slowly crumbled away, and the stars went out one by one" (41).

A week later, Aisha decided to drop off school because she could not get on well with her British friends' racist treatment, based on discrimination. In spite of her parents' refusal of that decision, she made up her mind to settle in her imaginary world and submit to the restrictions of the society in which she had to live, away from the real world "I knew now there was no hidden world, no secret society from which I was barred, there was just-nothing" (41). Aisha spent her days reading books and watching television, "Every morning. I would draw up my father's large armchair in front of the television, as well as preparing for her exam; "I spent my fifteenth year in a lotus dream, sunk in an armchair, throbbing to the Stones, reading erotica. And I passed my exam" (43).

The two bad experiences she passed through in the new community completed her feeling of loss and diaspora, she no longer had the power to face the daily clashes she met every day from people around her in her neighborhood and in school, she decided to surrender and face this world with submission and escape to her own world where everything is under her control. And where there is no difference between the customs 
she was brought up on and what she really encounters in the new society.

There are many female characters in the stories, but their dilemma is one. They all have that feeling of diaspora and displacement. Going on reading the stories and moving to the story of Zaina, we see how cruelly the other females treat Zaina, the bride on her wedding night only because she was a bit afraid because it is the first time for her to have a relation with a man, she is the victim of the traditions and customs of her society:

Suddenly the four women surrounded me and pulled me to the floor...I was yelling and screaming but I kept my thighs tight together. My uncle hammered on the door: "What the Hell's going on in there? Curse you all. Shall I come in and shoot the bitch? (Souif 91).

It is obvious too to notice how women are sometimes used as tools of torture against their likes. Instead of offering help to her in that serious and critical situation, we find the female relatives too participate in making her suffer and leave her soul in complete diaspora more and more:

It is all right, my brother, have patience," cried my aunt and bent down suddenly and bit my 


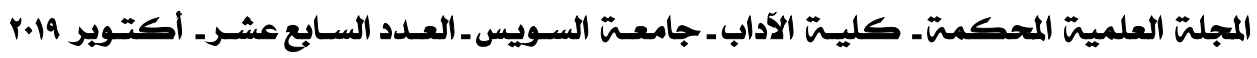

upper thigh so hard I jerked it away and they immediately pulled my legs apart and held them and he stepped forward and squatted between them. I managed to wrench a leg away as he leaned forward, I gave him a mighty kick that sent him sprawling on his backside... (Souif 91).

On her wedding night which is supposed to be the happiest night in her life, and instead of living moments of romance with her husband, it turns to be like an arena for fighting and kicking. Ahdaf Souif presents some of the hardest scenes ever, although these events used to happen a long time ago, yet they still have a deep impact and scar on every lady that had to live those moments of horror, terror, and panic:

Then he jumped up and came at me and slapped my face, then using all his man's strength he forced my thighs open, threaded one of my arms behind each knee and drew them to my head.... (Souif 91).

When she was 25 years old, her husband Sobhy took a young girl, Tahiya, as a second wife. Zaina was very jealous, but there was nothing she could do to stop the marriage. She kept talking to herself: 


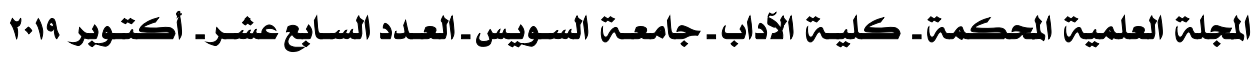

How can I drive him further away than he's already gone? To marry on top of me? Why? Am I old? Or has my hair gone white? Or am I ugly? Or have my teeth fallen out? Or don't I please him anymore? Or am I not a good housewife? Haven't I borne him a son and a daughter; May God have mercy on her? What is wrong with me that he should marry on top of me? (Souif 98).

Instead of blaming her husband, Zaina started to hate the new wife. Together with her sister and mother, she made a plan to get rid of her opponent, by accusing Tahiya of being treacherous. While their husband was away, Tahiya walked into Zaina's bedroom at night, as she was afraid of the stormy weather outside. Zaina started to seduce the younger wife and this caused some bruises and marks on Tahiya's thighs. Sobhy discovered these marks, and he was fully convinced that Tahiya had slept with another man. He divorced her and threw her out of the house. Zaina's plan was a great success.

You bitch. You whore. You got (the mark) it from your lover. Who is he? Tell me so that I can find him and drink his blood. I swear if you weren't Shiekh Mahgoub's daughter, I'd murder you this instant. Get your clothes together and get off to your mother's, you bitch. You are divorced. I don't want to see your face again. I have a mind to drag 


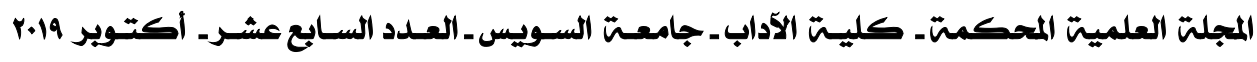

you out into the street and make a spectacle of you, you dirty slut- (Souif 112).

This story is the severest. Even though Zaina was the noticeable victim, as she is the main character in this story, we feel more sympathy for Tahiya for many reasons. Unlike Zaina, Tahiya had no family and nowhere to go. She was married to a man who was more than 15 years older than herself, and was forced to live with Zaina, who strongly disliked her. In addition to all this, Tahiya was really naive. Zaina is oppressed by her husband and handled this by oppressing Tahiya. This is, unfortunately, a very common way to react. When being treated badly by those in power, you usually act the same way towards persons in those you are in power of. Soeif managed to describe this nicely. I recommend "Aisha" as it is a true eye-opener for women situation in Middle East. Tahiya had that deep feeling of diaspora too in her heart and unable to drive it out. The feeling of being torn between different customs and traditions is thoroughly discussed in Walid Abdallah's Shout of Silence (2015) as he states that "She had nothing to do to prove her innocence except silence. She suffered greatly not only from her man, but she also tasted injustice by his wife." (11) 


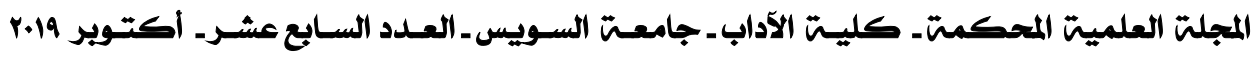

Surprisingly Zaina who comes from a lower-class family and goes on describing the most terrible experience she passed through during her wedding night where she has to face the old and forbidden traditions and rituals of the village to prove that she is a girl of honor. Ironically, Zaina later admits that she likes her 'big" husband and prepares a clever plan to get rid of his new, second wife.

Afterwards Setti explained that he was my husband and any time he wanted to do anything with me I must let him and not fight him. But I did," Zaina said, laughing "I fought with him every time for a month, but in the end, he mastered me."

“Did you hate him, Dada?' the child asked gently.

Zaina laughed again, easily. "No, of course not. He was a strong man, bless him. And besides he was as big as a bull. (Souif 92)

Edward Said writes about Soueif's distinguished style of writing by creating a charming mixture of the western and the Egyptian forms in writing her short stories:

In this small-scale and intimate first collection of stories by Ahdaf Souif there is a remarkably productive, somewhat depressing tension between the anecdotal surface of modern, Westernized 


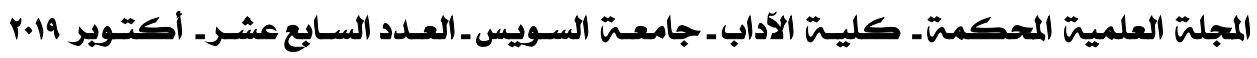

Egyptian life and the troubling, often violent but always persisting traditional forms beneath. (8)

Said emphasizes that Souif not only sheds light on crimes of violence against the woman and her regular feeling of diaspora, but she also draws our attention towards all types of clashes and aggression against woman whether it is physical or psychological. She keeps fighting all forms of violence such as their suffering from diaspora imposed on their lives, Marian is also torn between the clashes of getting married to a man she might love or a man that comes from a rich family and satisfies her greedy and selfish needs:

In one story, cajoled and pleaded to by her family and importunate suitors, Mariana is nevertheless seduced by an engineer whose Eau Sauvage, silk robe and Zamalek flat are to her the height of an irresistible worldliness: after she becomes his mistress it is discovered, however, that he runs a vice ring. Her brief revolt against the code governing nubile women is thereafter quelled, and she marries an uninteresting bourgeois who perfectly suits her family's idea of what a good husband should be. (8) 
Edward Said goes on analyzing the stories to reveal the secrets and the sufferings of the girls in their different lives, talking about Aisha's saying that she is the daughter of:

Academics on sabbatical in England, child of postrevolutionary Egypt, product of a partly Islamic and native upbringing, Aisha is the central consciousness of these eight stories. They form a cycle of experiences, from childhood to marital estrangement, to death; the lives of friends, relatives, lovers, family retainers intersect with hers, and when she dies, she is transmuted by Souif into an object of reflection and reminiscence for a self-conscious narrator. This last gesture isn't very convincing; as if the author had decided that she couldn't leave Aisha to descriptive realism but at the last minute had to point out the presence of a significant narrative process. (Said 8)

It is crystal-clear that Ahdaf Soueif was greatly affected by Arab writers like Yusuf Idris and Tayeb Salih and this is apparent in her style of writing. These are major writers who were the first to write about sexual customs, diaspora, hybridity and gender issues in Egypt and Sudan during the 1960s. It is true that these themes are found in nearly all of Soueif's writings, including the two short stories: "The Wedding of Zeina" and "Her Man". Soueif can be identified both as a 


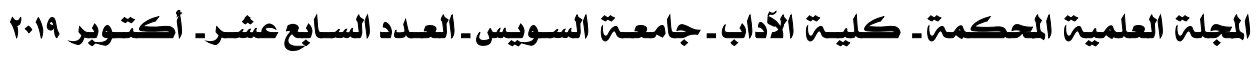

modern Arab-Muslim and postcolonial feminist writer since she is an Anglophone novelist born in Egypt and lives in England. Wail Hassan in his essay Immigrant Narratives (2012) confirms that Soueif is a post-colonial writer "She is much more concerned with cross-cultural issues; her works are firmly established in the spheres of the Arab-Muslim literary canon as well as in the international scope of postcolonial literature" (159-160). Diaspora, a main concept of postcolonialism, also appears clearly when we meet Aisha 's impossibly discriminating friend Mimi who regularly refuses a dozen of fiancés on the basis that their ears, pants or shoes are intolerable to confirm the concept of the clash between inside and outside, until she breaks her heart by a real villain and learns to be more indulgent. She is the most diasporic character as she can not accept the traditions of her society. She is torn between what society offers and what she aspires to.

Furthermore, many critics cannot decide on Soueif's literary identity, it is not easy for them to determine whether she belongs to Arab-Egyptian or to British postcolonial literature. Sindelarova states:

Soueif has often maintained that her creative and personal identity does not pose any further questions because she is an Egyptian who merely happens to write in English. And yet, it is not possible to agree 
totally with her approach for it is never a simple question of deciding about one's sense of belonging (15).

Moreover, concerning Soueif's stories, it is easy to find out that they are not influenced only by British authors like Charles Dickens and Georges Eliot. Rather, Soueif's writings are greatly affected by former Arab writings like those of Mahfouz and Saleh, she was greatly influenced by the postcolonial writers in Arabic like Nawal al-Saadawi, Fadia Fakir, Hanan al Shaykh and more. Therefore, "Soueif forms a complementary part of contemporary Arab literature and postcolonial feminist writing since she concentrates mainly on female characters and formulates their concerns and aspirations, whilst projecting obstacles to their hope within a conservative thinking" (16).

We can safely say that Ahdaf Soueif's Aisha discusses different forms oppression and aggression that an Arab Muslim woman has to face and encounter in Europe. Brahimi in her article Aisha's Encounters with the Other as a Confined/ Liberated Woman (2014) states that:

The alternative new portrait of Aisha draws her as a liberated woman demystifying her image as a stereotype. Aisha discovers new visions and perceptions of herself and the other. This 


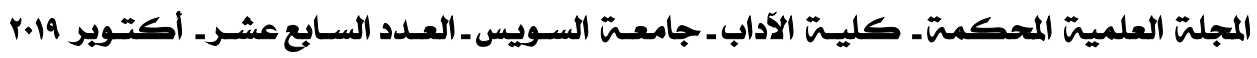

investigation will highlight Aisha's encounter with pertinent elements in the narrative respectively character, mainly male, time past and time present, besides space. These encounters will first confirm Aisha's old portrait and then allow the sketching of a brand new one (2).

Because Ahdaf Soueif comes from two different cultural backgrounds and speaks both Arabic and English fluently, it makes her more powerful and truthful in depicting the life of females that is torn between the old and the new in their life, Areeg (2015) states:

Soueif, who lives in the West and writes in English, is thus more straightforward when identifying herself with feminism. That is because writing in a language other than one's mother tongue is more liberating; for, English allowed Soueif and her conscious feminist narrative voice to infiltrate taboo terrains (15).

Edward Said (1983), whose essays have often concentrated on the cultural issues, being the basis of orientalism (the Western perceptions of the East), sees that Soueif's first collection of short stories Aisha was written with a high level of creativity and innovation:

Aisha is the central consciousness of these eight stories. They form a cycle of experiences, from 


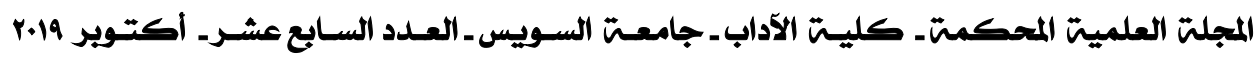

childhood to marital estrangement, to death; the lives of friends, relatives, lovers, family retainers intersect with hers...Soueif is perhaps uncritically attached to the idea of making each story build to a final, usually clever „point...The stories" coherence derives from the Egyptian subject-matter, which is neither eroticized nor submitted to explanatory or ideological explanations (1).

Aisha is the symbol of the Arab Muslim female who suffers greatly from diaspora, hybridity and displacement, and that nobody is going to hear her shouts or listen to her moans, so she prefers to escape into reading day and night and creates stories in which protagonists can say no, can shout, have the ability to fight for their survival and are able to refuse the their eternal feeling of alienation and hybridization. 


\section{Conclusion}

No one can deny the fact that people who live in multicultural communities are victimized by identity crisis as a result of cultural clash which Bano, (2015) has called 'cultural shock'. Soueif's migratory experience and the interpretation of it in her character Aisha revealed the ambiguous image of cultural amalgamation, resolving identities across borders. In post-colonial discourse, Diaspora and Hybridity are the two main concepts which are at the base of identity crisis that Aisha suffered. As Bhaba (1994) regards hybridity 'in between' space between two culture, so was Soueif's case as she belonged to nowhere and being a victim of identity crisis she settled and adapted but could not eliminate the effects of her homeland which Fareed (2013) has also noticed and stated that 'Diasporic people ever after being assimilated into new culture can never erase the memories of their past.

In the first place, in her first collection of short stories Aisha (1983) the Egyptian author Ahdaf Soueif sheds light on women's social, economic, political and inner troubles. She shows her main female characters - women-as being lost, diasporic, hybrid and weak because of their cultural customs and social norms they were brought up on. Consequently, they believe they are inferior to men and are always marginalized. Furthermore, the way the Muslim woman lives in her own 
context and that one she lives in Europe is found in Soueif's different short stories, for as being an Arab Muslim woman she writes about women and the Muslims' misbehavior towards women. She describes, as well, those Europeans who insult and laugh at Muslim women because of their clothing or the way they behave.

Although women are granted rights to different aspects like; education, economy, inheritance and property rights, many of them face several obstacles to get such rights as they live in a male dominated society where patriarchy is the norm. Such society does not respect or welcome women's rights and just disregard their ability to learn, work and succeed in several fields, accordingly the woman always feels diasporic. The phenomenon of getting women married by force is widespread in some Muslim communities which refers to the marriage of a man and a woman without their approval or without the consent of only one side, though Islam insists that marriage should be performed with complete satisfaction and this is a deep psychological clash that women usually suffer from. Certainly, there are numerous reasons that lead to such marriages as for example; those who believe in marriage as for a better social rank and no more than that, and those who want to wed their daughters just to protect them, in addition to many other reasons. 
The paper incorporates from one perspective a phenomenon found in Muslim social orders as well as in nonMuslims, as well. It is polygamy which implies that men can wed up to four spouses, which is additionally much rehearsed inside Muslim settings. It offends women, prompts conjugal inconveniences and causes an inner conflict. Then again, separation is likewise one issue that Muslim ladies face however Islam disgraces it for its negative results. This act leaves a deep scar in women's hearts and leave them in complete diaspora.

Muslim women living in Europe suffer from being marginalized, rejected and diasporic in the way that they are not welcome among Europeans because of their religion in addition to the way they dress. As the Muslim woman goes out with a veil in public, the Europeans show religious racism throughout their behaviors and believe that veiling is a result of gender inequality. They also face the evil of discrimination in schools and when asking for employment which leads to some Islamophobic incidents. In other words, women who cover themselves cannot learn comfortably and have no right to get a job. In fact, the media portrayal of Muslims and Islam is the main reason that helps those westerners to think about Muslims the way they do. Using invented and fake images, they could frame the worst person and call them "Muslim". 


\section{Works Cited}

- Abdallah, Walid. Shout of Silence, LAP Lambert Academic Publishing, 2015.

- Al Ariss, Tarek. Little Mosque on the Prairie, Caroll and Graf Publishers, 2006.

- Ashcroft, Bill, and Gareth Griffiths, and Helen Tiffin. "The Empire Writes Back: Theory and practice in postcolonial literatures. London: Routledge, (1989).

- Aschcroft, Bill. Gareth Griffiths and Helen Tiffin, Postcolonial Studies, the Key Concept, Routledge, 1998.

- Bhabha, Homi. K. The Location of Culture. London: Routledge Print, (1994).

- Baldick, Chris. The Oxford Dictionary of Literary Terms Oxford, 2008.

- Bano, Shamenaz. "Diasporic consciousness as reflected in the novels of Salman Rushdie and Bapsi Sidhwa" An International Multi-Disciplinary -e-Journal 1.1 (2015).

- Blain, Virginia. The Feminist Companion to Literature in English from the Middle Ages to the Present. New Haven: Yale University Press, 1990.

- Brahimi, Samira. "Aisha's Encounters with the Other as a Confined/ Liberated Woman". International Journal of Research in Applied, Natural and Social Sciences. 02: (2014), pp 2-7. 
- Chodorow, Nancy. Feminism and Psychoanalytic Theory. New Haven: Yale University, 1989.

- Clifford, James "Diaspora" Cultural Anthropology, Vol 9, No. 3 (1994).-

- Fareed, Sadaf, "Sidhwa's An American Brat: Cultural Assimilation with transitional identity" Journal of Higher Education and research Society 1.1(2013).

-George, Rosemary Marangoly. "At a slight angle to reality: reading Indian Diaspora literature". In the Society for the study of the Multi-Ethnic Literature of the United States (MLUS), (1996).

-Ghazoul, Ferial J (ed), The Hybrid Literary Text, Alif, no. 20, American University in Cairo Press, 2000, p. 6

-Gilbert, Sandra. Paperbacks: From our Mothers' Libraries: Women Who Created the Novel: New York Times, 4 May 1986.

-Gillan, Carol. In a Different Voice: Women's Conceptions of Self and Morality. Harvard Educational Review (47), 1977.

- Hassan, Wail, S. "Immigrant Narratives: Orientalism and Cultural Translation in Arab American and Arab British Literature". Postcolonial Text, Vol7, N4. 2012: pp 159, 160. -Ibrahim, Areeg. The Oppressive Oppressed in Miral AlTahawy's Blue Aubergine and Ahdaf Soueif's Aisha, Harvard University, 2010.

-Said, Edward. London Review of Literature, Vol.5 No.12, July 1983. 
-Sarnou, Dallel. Narratives of Arab Anglophone Women and the Articulation of a Major Discourse in A Minor Literature, Interdisciplinary Political and Cultural Journal, Vol. 16, No. $1 / 2014$.

-Schaffner, C. and Adab, B. (2001). The Idea of the Hybrid Text in Translation: Contact as Conflict. Across Languages and Cultures 2(2), pp.167-180

-Sidhwa, Bapsi, An American Brat, Penguin India: New Delhi, 1993. Print Imtiaz, Sana. "Speaking in Tongues: Conceptualizing Femininities in Sidhwa's An American Brat”. American International Journal of Contemporary Research 1.2(2011).

- Sindelarova, Alena. The Aspects of Bilingualism in the Literary Works of Ahdaf Soueif.Prague: Charles University, 2008.

-Soeif, Ahdaf. Aisha, Bloomsbury Publishing PLC; New edition (8 Feb 1996).

-Soueif, Ahdaf. Mezzaterra: Fragments from the Common Ground. London \& New York: Bloomsbury, 2004

- Trabelsi, Hechmi. "Transcultural Writings: Ahdaf Soueif's Aisha as a Case Study”. Jouvert. 7: (2003). P1

-Welsch, Wolfgang. "On the Acquisition and Possession of Commonalities." Transcultural English Studies: Theories, Fictions, Realities: 3-36 